DE

M E D I C I N A

T R O P I C A L

$\mathrm{DE}$

SÃO PAULO

JOURNAL OF THE SÃO PAULO INSTITUTE OF TROPICAL MEDICINE

${ }^{1}$ Universidade Feevale, Laboratório de Microbiologia Molecular, Novo Hamburgo, Rio Grande do Sul, Brazil

Correspondence to: Fernanda Gil de Souza

Universidade Feevale, Laboratório de Microbiologia Molecular, Campus II, RS 239, CEP 93352-000, Novo Hamburgo, RS, Brazil

Tel: +55 $513586-8800$

E-mail: nandags10@ hotmail.com

Received: 4 July 2018

Accepted: 24 September 2018

\section{Low occurrence of Hepatitis A virus in water samples from an urban area of Southern Brazil}

\author{
Fernanda Gil de Souza', Francini Pereira da Silva', Rodrigo Staggemeier', \\ Caroline Rigotto', Fernando Rosado Spilki ${ }^{1}$
}

\section{ABSTRACT}

Hepatitis A virus (HAV), a member of Picornaviridae family, is the main causative agent of acute viral hepatitis in the world, mainly in developing countries. HAV may be present in contaminated water and food and its presence is often associated to a lesser extent with socioeconomic factors and environmental quality. The main goals in the present study were to standardize a cell culture combined to a polymerase chain reaction protocol for the detection and quantification of viral viability and analyze whether the virus could be found in water samples collected in four urban streams of Sinos River watershed. Virus recovery was assayed from known virus concentrations measured in experimentally contaminated raw and ultrapure water (MilliQ ${ }^{\circledR}$ ). Recovery rates ranged from $270 \%$ in raw water to $15,000 \%$ in ultrapure water. In a second step, a qPCR coupled to a previous passage in cells, demonstrated more analytical sensitivity when compared to samples assayed without a previous passage in cell cultures. HAV genome was detected in only 1 of 84 samples analyzed, pointing to a very low occurrence of HAV in water samples in the studied region. These findings are remarkable, since no more than $5 \%$ of the domestic sewage in this area is treated pointing to a low occurrence of HAV in the population living nearby during the study period.

KEYWORDS: HAV. Stream. ICC-PCR. RT-PCR. Hepatitis. Nested-RT-PCR. Enteric virus.

\section{INTRODUCTION}

Hepatitis A virus (HAV) belongs to the genus Hepatovirus, within the Picornaviridae family, order Picornavirales. The genome is composed of a positive single-stranded RNA, with approximately $7.5 \mathrm{~Kb}$ of length ${ }^{1}$. Two noncoding regions are found in the genome flanking regions nominated P1 (comprising the ORF encoding the structural proteins VP1, VP2, VP3 and VP4) and P2 and P3, which encodes non-structural proteins related to viral replication ${ }^{1}$. HAV capsids are icosahedral and the viral particle is non-enveloped, thus being resistant under environmental conditions, although the virus is transitionally enveloped during traffic from the liver to the intestinal epithelium ${ }^{1,2}$. Three of the 6 HAV genotypes are associated with infections in humans (I-III) ${ }^{3}$.

HAV particles are highly stable in the environment and may be detected for long periods in various matrices such as surface and groundwater, sea waters and sediments ${ }^{4}$. Through the years, HAV outbreaks have been reported with increased frequency in large urban areas ${ }^{1}$. HAV outbreaks are related mostly to low socioeconomic levels and low environmental sanitation ${ }^{1}$. The spread of the virus through contaminated water and food increased the number of individuals who became not naturally immunized in so called developed regions. Actually, 
the absence of children vaccination in many places poses a challenge for the control of HAV infections nowadays ${ }^{5}$. As water and food brought up the nature of the infection, it is a priori advisable that studies on the environmental monitoring of HAV should be done, aiming to fulfill the knowledge about the epidemiology, whenever it is possible.

In Brazil, hepatitis A is a great matter of concern to public health, especially in the Northern part of the country. Children's immunization has been routinely implemented. Since 2014, the vaccine was included in the governmental calendar, increasing the access to immunization. In Rio Grande do Sul, the Southernmost Brazilian State, HAV cases decayed in the last 10 years. In 2014, there was a very low prevalence of the disease, with no more than 100 cases reported ${ }^{6}$. Many studies in other parts of the country showed a decrease of less than half that would be related to the viral prevalence in environmental samples ${ }^{7,8}$.

Molecular-based methods are useful for the detection of HAV genomes in water samples ${ }^{9}$. Adoption of protocols integrating molecular detection with cell culture, namely ICC-PCR, may allow inferring about the viral viability, providing information on the infectivity and health risks ${ }^{10}$. Additional ICC-PCR benefits may also include removal of inhibitors and increasing of viral particles counting through a cell passage, thus enhancing the analytical sensitivity of the technique when compared to molecular or cell-based detections alone ${ }^{11}$.

The main goal of the present study was to standardize and apply molecular techniques coupled to a cell culture, the polymerase chain reaction providing quantification and evaluation of HAV viral viability in water samples from streams in urban areas of the Sinos River watershed. This watershed is highly impacted by discharges of untreated domestic sewer in water bodies, and has been used as the main source of drinking water for nearly 1.500 .000 inhabitants, and the waters were previously found to be contaminated by other enteric viruses ${ }^{12,13}$.

\section{MATERIALS E METHODS}

\section{Samples}

From 2012 to 2014, $0.5 \mathrm{~L}$ of water samples were collected, aseptically bimonthly, in four streams crossing 4 cities of Sinos River watershed: Estancia Velha/Portao (cities of Estancia Velha and Portao, 73,494 habitants), Schmidt (Campo Bom city, 60,074 habitants), Pampa and Luiz Rau (both located in Novo Hamburgo city, 238,940 habitants, Figure 1); two samples per stream, near the source and the mouth, totaling 84 samples. Water samples were transported to the laboratory in freezer blocks.
Afterwards, samples were kept at $4{ }^{\circ} \mathrm{C}$ until processing. As mentioned before, this period was characterized by a very low prevalence of HAV-induced hepatitis in this region according to official reports.

\section{Viral concentration}

Samples were concentrated by an adapted adsorptionelution method ${ }^{14}$ described before ${ }^{15}$. Briefly, before filtration, $\mathrm{pH}$ was measured and adjusted to 4.5-5.5. Afterwards, $12.5 \mathrm{~mL}$ of $\mathrm{MgCl}_{2} 1 \mathrm{M}$ were added to samples. Five hundred millilitres of samples were filtered with the aid of a vacuum pump $(760 \mathrm{~mm} \mathrm{Hg})$, using a $0.45 \mu \mathrm{m}$ nitrocellulose negatively charged membrane (HA $47 \mathrm{~mm}$, Millipore $^{(\circledast)}$ ), for the adsorption of viral particles present in the sample; $87.5 \mathrm{~mL}$ of $0.5 \mathrm{mM} \mathrm{H}_{2} \mathrm{SO}_{4}$ was passed through the membrane to rinse out the cation. Then, $2.5 \mathrm{~mL}$ of solution $1 \mathrm{mM}$ of $\mathrm{NaOH}$ were added to the membrane for elution of viral particles. In $2.5 \mathrm{~mL}$ of the final eluate, $12.5 \mu \mathrm{L}$ of $50 \mathrm{mM} \mathrm{H}_{2} \mathrm{SO}_{4}$ solution and $12.5 \mu \mathrm{L}$ TE $100 \mathrm{X}$ buffer were added for neutralization, then samples were aliquoted and stored at $-80{ }^{\circ} \mathrm{C}$ until further processing.

\section{Viral nucleic acids extraction}

A volume of $400 \mathrm{uL}$ of the final viral eluate was submitted to nucleic acid extraction using $\mathrm{RTP}^{\circledR}$ DNA/ RNA Virus Mini Kit (Invitek ${ }^{\circledast}$, Germany), following the manufacturer's instructions. The final volume of $60 \mathrm{uL}$ containing putatively viral RNAs was stored at $-80^{\circ} \mathrm{C}$.

\section{Recovery of the viral concentration method}

To assay the viral recovery rates of the filtration-elution method described, aliquots of $500 \mathrm{~mL}$ of ultrapure RNAse/ DNAse free water (Direct $8^{\circledR}$, MilliQ ${ }^{\circledR}$ ) and of raw water of Pampa stream, previously tested negative for HAV, were artificially inoculated by spiking $1 \mathrm{~mL}$ of a viral suspension of $5.2 \times 10^{7} \mathrm{HAV}$ (HM 175) CG/ $5-\mu \mathrm{L}$. Before the viral inoculation, $1 \mathrm{~mL}$ of each sample vial was used as the negative control. Borosilicate bottles containing $500 \mathrm{~mL}$ of water were left closed at room temperature $\left(21^{\circ} \mathrm{C}\right)$ for $30 \mathrm{~min}$. Afterwards, $1 \mathrm{~mL}$ of each sample was aliquoted before the viral concentration by the method described above. Final eluates of $2.5 \mathrm{~mL}$ were stored at $-80{ }^{\circ} \mathrm{C}$ until further analysis. Viral genome extraction was performed directly from samples or after inoculating them into cell monolayers (ICC-RT-qPCR) as described above and the following types of samples were analyzed: 1) water before virus inoculation as the negative control (NC); 2) HAV inoculated in water before concentration (BC); 3) virus 


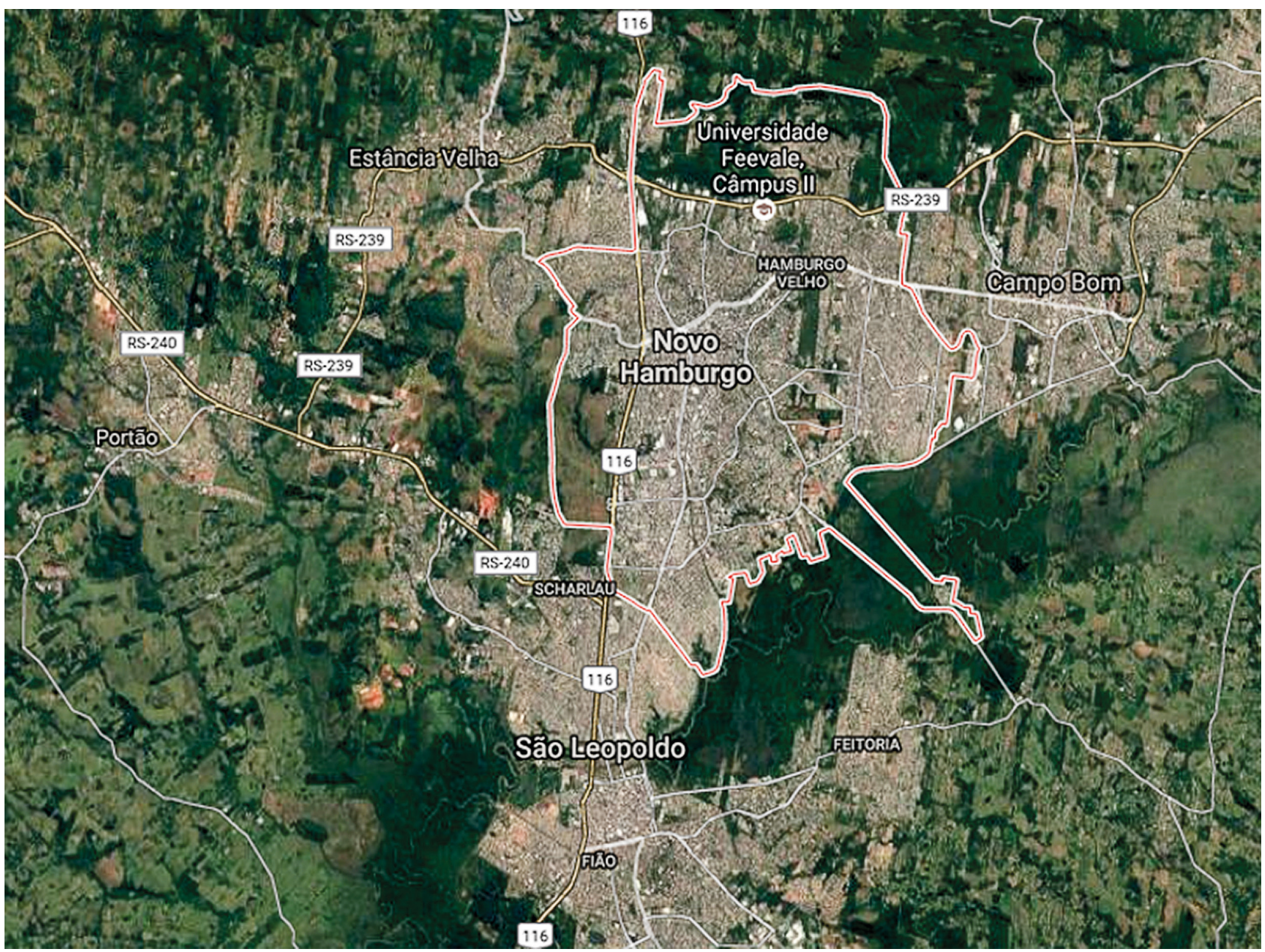

Figure 1 - Description of the counties Estancia Velha, Novo Hamburgo and Campo Bom.

inoculated in water after concentration, (AC); 4) virus that has a passageway by cell culture and analysis by ICC-RT-qPCR and Positive Control (PC).

\section{Recovery rate calculation}

Recovery rates were calculated using the values observed in the qPCR before the concentration process, defining as $100 \%$ of recovery, not evaluating losses in the processes of extraction and cDNA synthesis. Values obtained in $5 \mu \mathrm{L}$ after the process of concentration were divided by the values obtained before the process and multiplied by $100, X=b / a \times 100$, where $X=$ recovery rate $(\%), a=$ quantification result for $5 \mu \mathrm{L}$ by qPCR after concentration, and $\mathrm{b}=$ result for $5 \mu \mathrm{L}$ by qPCR before concentration.

\section{HAV genome detection}

Complementary DNA synthesis (cDNA) using the RNA extracted from samples and controls was performed using random primers of the High-Capacity cDNA Reverse Transcription kit ${ }^{\mathrm{TM}}$ (AppliedBiosystems ${ }^{\circledR}$, USA), following the manufacturer's instructions.

Forquantitative PCR (qPCR), primers andaTaqMan ${ }^{\circledR} \mathrm{HAV}$ specific probe were used aiming at amplifying the conserved noncoding region 5'-UTR of the HAV genome, described before $^{16}$ (sense 5'-GGTAGGCTACGGGTGAAAC-3'; reverse 5' -AACAACTCACCAATATCCGC-3'; probe FAM5'-CTTAGGCTAATACTTCTATGAAGAGATGC3'BHQ). All qPCR assays were performed using TaqMan ${ }^{\circledR}$ Universal PCR Master Mix (Applied Biosystems ${ }^{\circledR}$ ). For a final reaction volume of $20 \mu \mathrm{L}$, the reagents mixture contained $100 \mathrm{nM}$ of each primer and the Taqman ${ }^{\circledR}$ probe, and $5 \mu \mathrm{L}$ of cDNA. Each run was composed of 1 cycle of $60 \mathrm{~min}$, denaturation at $95^{\circ} \mathrm{C}$ for $15 \mathrm{~min}$, followed by 40 cycles of $95^{\circ} \mathrm{C}$ for $10 \mathrm{~s}, 55^{\circ} \mathrm{C}$ for $20 \mathrm{~s}$ and $72^{\circ} \mathrm{C}$ for $15 \mathrm{~s}$. All reactions performed in 48 wells microplates (MicroAmp Applied Biosystems) in a StepOne real-time PCR system (AppliedBiosystems ${ }^{\circledast}$, USA).

Positive (plasmids) and negative (RNAse/DNAse free water) controls were included, and standard curves were 
made using decimal serial dilutions from $10^{-1}$ to $10^{-10}$ genome copies of a plasmid containing the amplicon, kindly provided by Dr. Celia Barardi (Federal University of Santa Catarina, Brazil). Following the addition of $15 \mu \mathrm{L}$ of the reaction mixture and $5 \mu \mathrm{L}$ of cDNA, the microplate was sealed. All the samples and controls were tested in duplicate, to determine the efficiency and the limit of analytical sensitivity, values were calculated from a standard curve with dilution series of controls containing known concentrations of the target. Typical values obtained for efficiency were $103 \%$ and $\mathrm{R}^{2}=0.99$.

\section{Viral viability assay by ICC-RT-qPCR}

Viral viability evaluation was performed using RT-PCR real time assay coupled to cell culture (ICC-RT-qPCR integrated cell culture $q P C R$ ). This assay aims to detect possible infectious viral particles in environmental or biological samples. For the ICC-RT-qPCR, FRKH-4 cells (Rhesus Monkey Kidney Fibroblasts) were cultivated in 24-well plates $\left(2.5 \times 10^{5}\right.$ cells/well $)$ at $37{ }^{\circ} \mathrm{C}$ and $5 \% \mathrm{CO}_{2}$ atmosphere until cellular confluence. Afterwards, $500 \mu \mathrm{L}$ of the following were added to each well: concentrated water samples diluted 1:2 (non-cytotoxic dilution) and sterilized in $0.22 \mu \mathrm{m}$ membranes positive control (HAV HM175 5.2 x 10 $0^{7} \mathrm{CG} / 5 \mu \mathrm{L}$ ) and negative control (Eagle's minimum essential medium - E-MEM). After $1 \mathrm{~h}$ of viral adsorption and uniform shaking, every $15 \mathrm{~min}$, the initial inoculum was removed. In each plate cavity, $1 \mathrm{~mL}$ of E-MEM containing $1 \%$ of antibiotics (penicillin and streptomycin) and $2 \%$ of fetal bovine serum (FBS, Cultilab $^{\circledast}$ ) was added. Cell monolayers were incubated for $72 \mathrm{~h}$ at $37^{\circ} \mathrm{C}$ in atmosphere with $5 \%$ of $\mathrm{CO}_{2}$. Afterwards, the supernatant of each cavity was removed and the lysis buffer was added directly to the monolayer cell. Cell lysates were transferred to $1.5 \mathrm{~mL}$ microtubes and the nucleic acids extraction, cDNA synthesis and qPCRs were performed previously described protocols.

\section{RESULTS}

The analytical sensitivity of qPCR fell under 100 genomic copies in serial dilution curves performed with plasmid dilutions. During viral recovery assays using HAVspiked in ultrapure water, the minimum viral detection limit was 3 genomic copies, when PCR was coupled to cell culture (Table 1).

The viral concentration protocol was efficient, as inferred from the results of recovery assays, because quantification was $150 \mathrm{X}$ higher in ultrapure concentrated water with $6.3 \times 10^{4} \mathrm{GC} / 5 \mu \mathrm{L}$ (genomic copies/ $5 \mu \mathrm{L}$ ) than in non-concentrated water samples with $4.2 \times 10^{2}$ GC $/ 5 \mu \mathrm{L}$ (Table 2). In assays performed with ultrapure water samples spiked with HAV after the described cell culture (Table 1), it was possible to observe an increase of approximately $1 \log$ in the quantification when compared to samples assayed without a cell culture step (Table 2). Before concentration, in samples assayed without a cell culture step, the value was $4.2 \times 10^{2} \mathrm{GC} / 5 \mu \mathrm{L}$ and after cell culture, the value was $1.1 \times 10^{3} \mathrm{GC} / 5 \mu \mathrm{L}$. After concentration, in samples assayed without a cell culture step, the value was $6.3 \times 10^{4} \mathrm{GC} / 5 \mu \mathrm{L}$ and after cell culture, the value was $1.3 \times 10^{5}$. From the environmental samples analyzed, only one was HAV-positive $\left(1.5 \times 10^{4} \mathrm{cg} / \mathrm{L}\right)$ coming from point 4 of the Pampa stream, which crosses

Table 1 - Analytical sensitivity limit of ICC-qPCR reaction to Hepatitis A virus artificially inoculated in ultrapure water before and after the viral concentration process by the adsorptionelution method.

\begin{tabular}{ccc}
\hline $\begin{array}{c}\text { Sample } \\
\text { dilutions }\end{array}$ & $\begin{array}{c}\text { Quantification before } \\
\text { concentration }\end{array}$ & $\begin{array}{c}\text { Quantification after } \\
\text { concentration }^{\mathrm{a}}\end{array}$ \\
\hline $\begin{array}{c}\text { Non-diluted } \\
10^{-1}\end{array}$ & $1.1 \times 10^{3}$ & $1.3 \times 10^{5}$ \\
$10^{-2}$ & $1.1 \times 10^{2}$ & $1.6 \times 10^{5}$ \\
$10^{-3}$ & 10 & $1.8 \times 10^{4}$ \\
$10^{-4}$ & 3 & $1.5 \times 10^{3}$ \\
\hline
\end{tabular}

${ }^{\mathrm{a}}$ values in genomic copies $/ 5 \mu \mathrm{L}$.

Table 2 - Recovery rates of Hepatitis A (HAV) virus before and after the adsorption-elution concentration method in ultrapure and raw experimentally contaminated water.

\begin{tabular}{lcc}
\hline Samples & Quantification $(\mathrm{CG} / 5 \mathrm{uL})$ & Recovery rate $(\%)$ \\
\hline Ultrapure water before inoculation & $\mathrm{Neg}$ & $\mathrm{Neg}$ \\
Ultrapure water + HAV before concentration & $4.2 \times 10^{2}$ & 100 \\
Ultrapure water + HAV after concentration & $6.3 \times 10^{4}$ & 15000 \\
Raw water before inoculation & $\mathrm{Neg}$ & $\mathrm{Neg}$ \\
Raw water + HAV before concentration & $1.04 \times 10^{3}$ & 100 \\
Raw water + HAV after_concentration & $2.7 \times 10^{3}$ & 270 \\
\hline
\end{tabular}


the larger city included in this study, namely Novo Hamburgo (July/2013).

\section{DISCUSSION}

ICC-PCR assays have been used for detecting several other enteric viruses in environmental samples ${ }^{10,17,18}$. The results have shown that the qPCR using TaqMan ${ }^{\circledR}$ was adapted to the integrated use proposed in the cell culture protocol, increases the technique sensitivity possibly by viral growth that may enhance the number of genome copies and decrease amplification inhibitors.

The recovery percentage in raw water was lower than in ultrapure water as expected, probably due to the presence of inhibitors. An increase in the quantification of raw samples was also observed. In other studies, the best recovery was found in distilled water and treated wastewater effluents $(100 \%)$, and the lowest recovery $(10 \%)$ in seawater ${ }^{19}$. In addition, like in this study, no detection of HAV was found in coastal water ${ }^{20}$ and for both, Norovirus (NoV) and Human astrovirus (HAstV), the recovery percentage from mineral and river water samples was between $18 \%$ and $64 \%{ }^{21}$.

These results show that the use of integrated cell culture to ensure the detection of HAV in water may favor analytical sensitivity, as it was observed in the past for other enteric viruses $^{22}$. Another advantage is the inference of measures to control infectivity and consequently the health risk posed by the presence of HAV particles in water ${ }^{18}$.

The Pampa stream is highly impacted and urbanized, receiving industrial garbage discharges and untreated sewer ${ }^{23}$. Other studies reported poor water quality conditions in this particular stream by monitoring of physical and chemical parameters ${ }^{12}$. Although the detection of a solely positive sample for HAV shows that no matter this stream has been hugely contaminated by domestic sewage, the detection of this virus under environmental matrices in often sporadic. No other samples were positive for HAV gene sequences, even after cell passages.

In another study conducted in the North region of Brazil, 23\% of HAV positive samples were detected by nested-RT-PCR and $92 \%$ using RT-qPCR, but it may be speculated that these samples were collected during or after HAV outbreaks ${ }^{7}$. The same may have happened in another survey on recreational seawater in Florianopolis, in which $46 \%$ of the samples were found to be contaminated by $\mathrm{HAV}^{24}$. On the other hand, many studies in Brazil showed low occurrence or absence of HAV in water, as has also been reported for the area of the study, regarding acute viral hepatitis of official government reports throughout the sampling period. In 2009, HAV was detected in $8.3 \%$ of freshwater samples from Florianopolis ${ }^{19}$ and no positive results for HAV were found in 108 samples analyzed in Rio de Janeiro ${ }^{25}$. Other studies have also shown a low incidence of HAV in environmental matrices, ranging from $20 \%$ to $32 \%$ positive samples, respectively, reinforcing the sporadic occurrence of HAV in surface waters in Brazil ${ }^{26,27}$.

However, since HAV is an endemic condition in Brazil, with the improvement of sanitation in recent decades, a decrease in the seroprevalence has been observed in several regions of the country. Unlike low endemic countries, the vaccine is only recommended depending on epidemiological studies of the region and risk groups involved, especially for children under five years old ${ }^{28}$.

\section{CONCLUSION}

Based on viral recovery assays and qPCR efficiency evaluation performed in this study and in the environmental samples analysis, we can conclude that there was a low virus occurrence in superficial waters in the region studied.

\section{ACKNOWLEDGMENTS}

This work was supported by Feevale University, the Coordination for the Improvement of Higher Level Personnel (CAPES), and the National Council for Scientific and Technological Development (CNPq).

\section{REFERENCES}

1. Sánchez G, Bosch A, Pintó RM. Hepatitis A virus detection in food: current and future prospects. Lett Appl Microbiol. 2007;45:1-5.

2. Feng Z, Hirai-Yuki A, McKnight KL, Lemon SM. Naked viruses that aren't always naked: quasi-enveloped agents of acute hepatitis. Annu Rev Microbiol. 2014;1:539-60.

3. Lima LR, De Almeida AJ, Tourinho RS, Hasselmann B, Ximenez LL, De Paula VS. Evidence of hepatitis A virus person-toperson transmission in household outbreaks. PLoS One. 2014;9:e102925.

4. Barardi CR, Viancelli A, Rigotto C, Corrêa AA, Moresco V, Souza DS, et al. Monitoring viruses in environmental samples. IJESER. 2012;3:62-79.

5. Jonas MM. Hepatitis A virus infection: progress made, more work to be done. J Pediatr (Rio J). 2011;87:185-6.

6. Rio Grande do Sul. Secretaria da Saúde. Centro Estadual de Vigilância em Saúde. Divisão de Vigilância Epidemiológica. Programa Estadual de Hepatites Virais. Dia mundial de luta contra as hepatites virais: 2018. [cited 2018 Oct 4] Available from: https://cevs.rs.gov.br/upload/ arquivos/201807/25114428-panorama-das-hepatites-viraisb-e-c-no-rs.pdf 
7. Schlindwein AD, Rigotto C, Simões CM, Barardi CR. Detection of enteric viruses in sewage sludge and treated wastewater effluent. Water Sci Technol. 2010;61:537-44.

8. Elmahdy ME, Fongaro G, Magri ME, Petruccio MM, Barardi CR. Spatial distribution of enteric viruses and somatic coli phages in a Lagoon used as drinking water source and recreation in Southern Brazil. Int J Hyg Environ Health. 2016;219:617-25.

9. De Paula VS, Diniz-Mendes L, Villar LM, Luz SL, Silva LA, Jesus MS, et al. Hepatitis A virus in environmental water samples from the Amazon Basin. Water Res. 2007;41:1169-76.

10. Rigotto C, Victoria M, Moresco V, Kolesnikovas CK, Corrêa AA, Souza DS, et al. Assessment of adenovirus, hepatitis A virus and rotavirus presence in environmental samples in Florianopolis, South Brazil. J Appl Microbiol. 2010;109:197987.

11. Gallagher EM, Margolin AB. Development of an integrated cell culture: real-time RT-PCR assay for detection of reovirus in biosolids. J Virol Methods. 2007;139:195-202.

12. Dalla Vecchia A, Rigotto C, Staggemeier R, Soliman MC, Souza FG, Henzel A, et al. Surface water quality in the Sinos River basin, in Southern Brazil: tracking microbiological contamination and correlation with physicochemical parameters. Environ Sci Pollut Res Int. 2015;22:9899-911.

13. Staggemeier R, Bortoluzzi M, Heck TM, Spilki FR, Almeida SE. Quantitative vs. conventional PCR for detection of human adenoviruses in water and sediment samples. Rev Inst Med Trop Sao Paulo. 2015;57:299-303.

14. Katayama H, Shimasaki A, Ohgaki S. Development of a Virus Concentration method and its application to detection of enterovirus and norwalk virus from coastal seawater. Appl Environ Microbiol. 2002;68:1033-9.

15. Dalla Vecchia A, Fleck JD, Comerlato J, Kluge M, Bergamaschi B, Silva JV, et al. First description of Adenovirus, Enterovirus, Rotavirus and Torque teno virus in water samples collected from the Arroio Dilúvio, Porto Alegre, Brazil. Braz J Biol. 2012;72:323-9.

16. Jothikumar N, Cromeans TL, Sobsey MD, Robertson BH. Development and evaluation of a broadly reactive TaqMan assay for rapid detection of hepatitis A virus. Appl Environ Microbiol. 2005;71:3359-63.

17. Rigotto C, Sincero TC, Simões CM, Barardi CR. Detection of adenoviruses in shellfish by means of conventional-PCR, nested-PCR, and integrated cell culture PCR (ICC/PCR). Water Res. 2005;39:297-304.
18. Rutjes SA, Lodder WJ, van Leeuwen AD, de Roda Husman AM. Detection of infectious rotavirus in naturally contaminated source waters for drinking water production. J Appl Microbiol. 2009;107:97-105.

19. Rigotto C, Kolesnikovas CK, Moresco V, Simões CM, Barardi CR. Evaluation of HA negatively charged membranes in the recovery of human adenoviruses and hepatitis A virus in different water matrices. Mem Inst Oswaldo Cruz. 2009;104:970-4.

20. Villar LM, De Paula VS, Diniz-Mendes L, Lampe E, Gaspar AM. Evaluation of methods used to concentrate and detect hepatitis A virus in water samples. J Virol Methods. 2006;137:169-76.

21. Victoria M, Guimarães F, Fumian T, Ferreira F, Vieira C, Leite JP, et al. Evaluation of an adsorption-elution method for detection of astrovirus and norovirus in environmental waters. J Virol Methods. 2009;156:73-6.

22. Dong Y, Kim J, Lewis GD. Evaluation of methodology for detection of human adenoviruses in wastewater, drinking water, stream water and recreational waters. J Appl Microbiol. 2010;108:800-9.

23. Nascimento CA, Naime R. Monitoramento de ph, temperatura, OD, DBO e condições microbiológicas das águas do arroio Pampa em Novo Hamburgo (RS). Est Tecnol. 2009;5:227-44.

24. Moresco V, Viancelli A, Nascimento MA, Souza DS, Ramos AP, Garcia LA, et al. Microbiological and physicochemical analysis of the coastal waters of southern Brazil. Mar Pollut Bull. 2012;64:40-8.

25. Miagostovich MP, Guimarães FR, Vieira CB, Fumian TM, Gama $\mathrm{NP}$, Victoria M, et al. Assessment of water quality in a border region between the Atlantic forest and an urbanized area in Rio de Janeiro, Brazil. Food Environ Virol. 2014;6:110-5.

26. Formiga-Cruz M, Hundesa A, Clemente-Casares P, AlbiñanaGimenez N, Allard A, Girones R. Nested multiplex PCR assay for detection of human enteric viruses in shellfish and sewage. J Virol Methods. 2005;125:111-8.

27. Villar LM, de Paula VS, Diniz-Mendes L, Guimarães FR, Ferreira FF, Shubo TC, et al. Molecular detection of hepatitis A virus in urban sewage in Rio de Janeiro, Brazil. Lett Appl Microbiol. 2007;45:168-73.

28. Ximénes RA, Martelli CM, Merchán-Hamann E, Montarroyos UR, Braga MC, de Lima ML, et al. Multilevel analysis of hepatitis A infection in children and adolescents: a household survey in the Northeast and Central-west regions of Brazil. Int J Epidemiol. 2008;37:852-61. 